\title{
PENERAPAN METODE PEMBELAJARAN KONSTRUKTIVISME UNTUK MENINGKATKAN HASIL BELAJAR GEOGRAFI PADA MATERI BENTUK-BENTUK PERMUKAAN BUMI UNTUK SISWA KELAS VII SMP GOTONG ROYONG TOBELO
}

\author{
Darling Surya Alnursa ${ }^{1}$, Andi Suaema ${ }^{2}$ \\ ${ }^{1,2}$ Dosen Prodi Pendidikan Geografi STIKIP Kieraha Ternate \\ Darling.alnursa@gmail.com, andisuaema2019@gmail.com
}

\begin{abstract}
The place of reserach at SMP Gotong Royong, Tobelo. This research aims at knowing the students' output through the constructivism application and to know improving the output after doing the learning process using construtivism. The method used in this reserach was qualitative in the shape of Classroom Action Research (CAR) and using two cycles. Each cycle consisted of planning, doing, and reflection. Based on the result of research, in the cycle 1, the average of the students' output is 62.08. This value has not get the minimum score or the criterium of minimum completness. In the cycle II, the average of the students' output is 71.25 , this means the students has got minimum score of achievement. The above result shows that the conducted research in cycle I to cycle II get significant improvement.
\end{abstract}

Keywords: constructivism learning, output, KKM

\section{PENDAHULUAN}

Penggunaan metode dalam pembelajaran sangat diutamakan guna menimbulkan gairah belajar, motivasi belajar, merangsang siswa berperan aktif dalam proses pembelajaran. Melalui metode Konstruktivismediharapkan dapat lebih mempermudah pemahaman materi pelajaran yang diberikan dan nantinya dapat mempertinggi kualitas proses pembelajaran yang selanjutnya dapat meningkatkan hasil belajar siswa.

Berdasarkan observasi nilai Kriteria Ketuntasan Minimum (KKM) SMP Gotong Royong Tobelo yaitu 75. Dari 100\% siswa yang berada di kelas VII, hanya 55\% siswa yang mencapai Kriteria Ketuntasan Minimum (KKM) sementara 45\% tidak mencapainya. Hal ini dikarenakan kurangnya kepercayaan diri yang terdapat dalam diri siswa atau siswa tidak bisa membanggakan kemampuan yang siswa miliki sehingga, siswa cenderung bergantung pada teman-temannya baik itu dalam proses belajar maupun pada saat tes dan kurangnya pemahaman siswa terhadap materi yang disampaikan oleh guru mata pelajaran. Hal ini diketahui dari hasil observasi yang dilakukan. Dari hasil observasi tersebut terlihat bahwa penerapan metode dan juga model pembelajaran yang diterapkan oleh guru belum maksimal. 
Sehingga Dalam proses pembelajaran terlihat masih rendah perhatian siswa dan juga siswa kurang berpartisipasi. Sehingga, perlu mencari solusi-solusi guna membantu siswa yang belum mencapai Kriteria Ketuntasan Minimum (KKM) tersebut.

Selain itu, rendahnya hasil belajar geografi disebabkan oleh masih dominannya skill menghafal daripada skill memproses sendiri pemahaman suatu materi. Selama ini, minat belajar siswa terhadap mata pelajaran geografi masih tergolong sangat rendah. Hal ini dapat dilihat pada sikap siswa selama mengikuti proses pembelajaran tidak fokus dan ramai sendiri. Bahkan ada sebagian siswa yang beranggapan bahwa mata pelajaran geografi itu hanya belajar tentang peta, atlas dan globe jadi tidak menarik. Faktor ini juga dipengaruhi oleh adanya metode mengajar yang digunakan guru dalam menyampaikan materi.

Metode yang konvensional seperti menjelaskan materi secara abstrak, hafalan materi dan ceramah dengan komunikasi satu arah, yang aktif masih didominasi oleh pengajar, sementara siswa biasanya hanya memfokuskan penglihatan dan pendengaran. Kondisi pembelajaran seperti inilah yang mengakibatkan siswa kurang aktif dan pembelajaran yang dilakukan kurang efektif. Disini guru dituntut untuk pandai menciptakan suasana pembelajaran yang menyenangkan bagi siswa sehingga siswa kembali berminat mengikuti kegiatan belajar. Diharapkan dengan menggunakan motode pembelajaran konstruktivisme dalam proses pembelajaran Geografi akan menarik minat siswa untuk mengikuti kegiatan belajar sehingga dapat meningkatkan hasil belajar siswa.

\section{Karakteristik Geografi}

Hasil seminar dan lokakarya Ikatan Geografi Indonesia (IGI) di Semarang tahun 1988 menyatakan bahwa geografi adalah ilmu yang mempelajari persamaan dan perbedaan fenomena geosfer dengan sudut pandang kewilayahan dan kelingkungan dalam konteks keruangan.

Sehingga Wardiyatmoko (2012: 67) mengatakan bahwa Geografi merupakan ilmu yang mempelajari atau mengkaji segala fenomena yang ada di permukaan bumi, seperti penduduk, fauna, flora, iklim, batuan, air, dan interaksi antara fenomena-fenomena tersebut. Dengan kata lain, geografi adalah studi tentang gejala-gejala di permukaan bumi secara keseluruhan dalam lingkup interaksi dan keruangan.

Hal ini menunjukan bahwa interaksi antara manusian dengan manusia dan antara manusian dengan benda-benda yang ada di permukaan bumi itu terjadi baik pada wilayah, lingkungan maupun pada ruang tertentu karena Ilmu georgrafi 
mengkaji Lingkungan hidup dengan istilah yang dapat mencakup segala makhluk hidup dan tak hidup, di alam yang ada di Bumi atau bagian dari bumi, yang berfungsi secara alami tanpa campur tangan manusia yang berlebihan.

\section{Konsep Konstruktivisme}

Menurut Brien dan Brant, kontsruktivisme adalah satu pendekatan pengajaran berdasarkan kepada penyelidikan tentang bagaimana manusia belajar (Sumiati dan Asra, 2009: 18). Semasa proses pengajaran dan pembelajaran, setiap individu akan membina pengetahuan mereka sendiri secara aktif dimana mereka bukan hanya menerima pengetahuan tersebut secara pasif daripada orang lain. Pelajar membina pengetahuan dan konsep secara aktif berdasarkan pengetahuan dan pengalaman.

Bagi pembangunan perisian berdasarkan teori konstuktivisme, ia menekankan perisian yang mempunyai perspektif yang pelbagai (multiple perspectives) seperti penggunaan alat kolaborasi dan komunikasi dan juga akses kepada data membolehkan pelajar belajar dari berbagai perspektif. Disamping itu, pembelajaran adalah berpusatkan pelajar yaitu pelajar akan mengaplikasikan sepenuhnya keupayaan mereka untuk bebas memilih apa yang ingin dipelajari, menjana persoalan sendiri serta merancang pembelajaran masing-masing.

Menurut Baharudin (2007: 29), teori konstruktivisme menggalakkan strategi penemuan dalam PBK yang akan dibangunkan. Aktifitas yang dilaksanakan oleh pelajar perlulah menggalakkan mereka menemui sendiri prinsip pelajaran.Guru pula tidak harus membantu member prinsip kepada pelajar untuk pengajaran dan pembelajaran yang berkesan. Dalam konteks ini, pelajar akan dibantu untuk membuat generalisasi berdasarkan pengetahuan mereka sendiri dan memindahkan pembelajaran kepada situasi lain dengan menggunakan konsep yang sama.

Untuk mengintegrasikan pendekatan konstruktivisme dalam pembelajaran geografi, George Bodner telah mencadangkan yaitu pengetahuan tidak boleh hanya disampaikan oleh guru kepada pelajar tetapi pelajar perlu membina pengetahuan baru dan pengalaman pengetahuan sedia ada mereka (Wiriatmadja, 2005: 36).Pelajar perlu menggunakan pengetahuan sedia ada untuk memperkembangkan maklumar baru yang telah mereka perolehi. Jika pengetahuan baru yang diperoleh dapat disesuaikan dengan pengetahuan sedia ada mereka, pengetahuan tersebut dapat diasimilasikan. Namun begitu, jika maklumat baru tersebut adalah berbeza, maklumat tersebut akan perlu diubah untuk diakomodasikan dengan pengetahuan baru. 


\section{Langkah-langkah Pembelajaran Konstruktivisme}

Langkah-langkah dalam pengelolaan pembelajaran yang konstruktivistis akan di lihat dari tiga sisi yakni; persiapan, pelaksanaan, dan evaluasi. Adapun penjelasannya yaitu sebagai berikut:

1. Sebelum guru mengajar (Tahap persiapan):

a. Mempersiapkan bahan yang mau di ajarkan;

b. Mempersiapkan pertanyaan dan arahan untuk merangsang siswa aktif belajar;

c. Mempelajari keadaan siswa, mengerti kelemahan dan kelebihan siswa

d. Mempelajari pengetahuan awal siswa;

2. Selama proses pembelajaran (tahap pelaksanaan):

a. Mengajak siswa aktif belajar;

b. Siswa dibiarkan bertanya;

c. Mengikuti pikiran dan gagasan siswa;

d. Menggunakan variasi metode pembelajaran;

e. Tidak mencerca siswa yang berpendapat salah atau lain;

f. Menerima jawaban alternative dari siswa;

g. Siswa diberi waktu berpikir dan merumuskan gagasan mereka;

h. Siswa diberi kesempatan mengungkapkan pikirannya;

i. Siswa diberi kesempatan untuk mencari pendekatan dengan caranya sendiri dalam belajar dan menemukan sesuatu;

j. Evaluasi yang kontinu dengan segala prosesnya.

3. Sesudah proses pembelajaran (tahap evaluasi)

a. Guru memberi pekerjaan rumah, mengumpulkannya, dan mengoreksinya;

b. Memberikan tugas lain untuk pendalaman;

c. Tes yang membuat siswa berpikir, bukan hafalan.

\section{Ciri-ciri Pendekatan Konstruktivisme}

Menurut Dahlan (1990: 61) ciri-ciri konstruktivisme, yaitu:

1. Belajar berarti membentuk makna;

2. Konstruksi arti itu dipengaruhi oleh pengertian yang telah ia punyai;

3. Belajar bukanlah kegiatan mengumpulkan fakta, melainkan lebih sebagai perkembangan pemikiran dengan membuat pegertian baru;

4. Proses belajar yang sebenanya terjadi pada waktu skema seseorang dalam keraguan yang merangsang pemikiran lebih lanjut; 
5. Hasil dipengaruhi oleh pengalaman siswa dengan dunia fisik dan lingkungan;

6. Hasil belajar seseorang tergantung pada apa yang telah diketahui si pelajar.

Setiap metode pembelajaran yang membantu siswa melakukan kegiatan dan akhirnya dapat mengkonstruksi pengetahuan yang mereka pelajari dengan baik, dapat dikatakan sebagi metode yang aktif dan konstruktivistik.Namun demikian, dapat pula di telusuri beberapa metode yang cukup efektif dalam mengaktifkan siswa dan membantu dalam pengkonstruksian di atas.Salah satu di antaranya adalah metode penemuan dengan penekanan pada kerangka berpikir metode ilmiah.

Dalam penerapan metode penemuan, siswa dilatih untuk terbiasa melakukan pengamatan, membuat hipotesis, memunculkan prediksi, memanipulasi objek untuk melihat perubahannya, memecahkan persoalan, mencarai jawaban sendiri, menggambarkan kejadian, meneliti, berdialog, melakukan refleksi, mengungkapkan pertanyaan, dan mengekspresikan gagasan selama proses pembentukan konstruksi pengetahuan yang baru.

\section{Kelebihan dan Kelemahan Konstruktivisme}

\section{Kelebihan}

a. Berfikir: alam proses membina pengetahuan baru, murid berfikir untuk menyelesaikan masalah, menjana idea dan membuat keputusan;

b. Faham:Oleh kerana murid terlibat secara langsung dalam mebina pengetahuan baru, mereka akan lebih faham dan boleh mengapliksikannya dalam semua situasi;

c. Ingat:Oleh kerana murid terlibat secara langsung dengan aktif, mereka akan ingat lebih lama semua konsep. Yakin siswa melalui pendekatan ini membina sendiri kefahaman mereka. Justeru mereka lebih yakin menghadapi dan menyelesaikan masalah dalam situasi baru;

d. Kemahiran sosial:Kemahiran sosial diperolehi apabila berinteraksi dengan rakan dan guru dalam membina pengetahuan baru;

e. Seronok:Oleh kerana mereka terlibat secara terus, mereka faham, ingat, yakin dan berinteraksi dengan sihat, maka mereka akan berasa seronok belajar dalam membina pengetahuan baru.

2. Kelemahan

Dalam bahasan kekurangan atau kelemahan ini mungkin bisa kita lihat dalam proses belajarnya dimana peran guru sebagai pendidik itu sepertinya kurang begitu mendukung. 
Beberapa kelebihan dalam pembelajaran ini adalah:
a. Pebelajar lebih memahami konsep yang diajarkan sebab mereka sendiri yang menemukan konsep tersebut;
b. Melibatkan secara aktif memecahkan maslah dan menuntut ketrampilan berfikir pebelajar yang lebih tinggi;
c. Pengetahuan tertanam berdasarkan skemata yang dimiliki pebelajar sehingga pembelajaran bermakna;
d. Pembelajar dapat merasakan manfaat pembelajaran sebab masalah- masalah yang diseleseikan langsung dikaitkan dengan kehidupan nyata, hal ini dapat meningkatkan motivasi dan ketertarikan pebelajar terhadap bahan yang dipelajari;
e. Menjadikan pebelajar lebih mandiri dan dewasa mampu memberi aspirasi dan menerima pendapat orang lain, menanamkan sikap sosial yang positif diantara pebelajar;
f. Pengkondisian pebelajar dalam belajar kelompok yang saling berinteraksi terhadap pembelajaran dan temuannya sehingga pencapaian kesempatan belajar pebelajar dapat diharapkan.

\section{Konsep Hasil Belajar}

Menurut Sudjana (2004: 112) hakikat hasil belajar adalah perubahan tingkah laku individu yang mencakup aspek kognitif, afektif, dan psikomotorik. Selain itu Sudjana (2004: 114)juga menjelaskan hasil belajar yang dicapai siswa dipengaruhi oleh dua faktor utama yakni faktor dari dalam diri siswa itu dan faktor yang datang dari luar diri siswa atau faktor lingkungan. Faktor yang datang dari diri siswa terutama kemampuan yang dimilikinya. Faktor kemampuan siswa besar sekali pengaruhnya terhadap hasil belajar yang dicapai. Disamping faktor kemampuan yang dimiliki siswa, juga ada faktor lain, seperti motivasi belajar, minat dan perhatian, sikap dan kebiasaan belajar, ketekunan, sosial ekonomi, faktor fisik dan psikis.

Hasil belajar merupakan segala upaya yang menyangkut aktivitas otak (proses berfikir) terutama dalam ranah kognitif, afektif, dan psikomotorik. Proses berfikir ini ada enam jenjang, mulai dari yang terendah sampai dengan jenjang tertinggi (Suharsimi Arikunto, 2005: 71). Keenam jenjang tersebut adalah: (1) Pengetahuan (knowledge) yaitu kemampuan seseorang untuk mengingat kembali tentang nama, istilah, ide, gejala, rumus- rumus dan lain sebagainya, tanpa mengharapkan kemampuan untuk menggunakannya. (2) Pemahaman (comprehension) yakni kemampuan seseorang untuk memahami sesuatu setelah 
sesuatu itu diketahui dan diingat melalui penjelasan dari kata- katanya sendiri. (3) Penerapan (application) yaitu kesanggupan seseorang untuk menggunakan ide- ide umum, tata cara atau metode- metode, prinsip- prinsip, rumus- rumus, teori- teori, dan lain sebagainya dalam situasi yang baru dan kongkret. (4) Analisis (analysis) yakni kemampuan seseorang untuk menguraikan suatu bahan atau keadaan menurut bagian- bagian yang lebih kecil dan mampu memahami hubungan diantara bagian- bagian tersebut. (5) Sintesis (synthesis) adalah kemampuan berfikir memadukan bagian- bagian atau unsur- unsur secara logis, sehingga menjadi suatu pola yang baru dan terstruktur. (6) Evaluasi (evaluation) yang merupakan jenjang berfikir paling tinggi dalam ranah kognitif menurut Taksonomi Bloom. Penelitian disini adalah kemampuan seseorang untuk membuat pertimbangan terhadap suatu situasi, nilai atau ide, atas beberapa pilihan kemudian menentukan pilihan nilai atau ide yang tepat sesuai kriteria yang ada.

Pada pendidikan formal, semua bidang studi dan bidang pendidikan harus memanfaatkan dasar mental yang ada pada tiap anak untuk meningatkan kemampuan mentalnya kearah kematangan dan kedewasaan dalam arti seluasluasnya. Oleh karena itu penyelenggara pendidikan dan pengajaran harus dilaksakan secara teratur, terarah, dan terencana sesuai dengan pengembangan dasar dan kemampuan mental anak, agar tujuan pendidikan dan pengajaran tercapai secara maksimal.

Dalam kegiatan belajar mengajar setiap guru selalu berusaha melakukan kegiatan pembelajaran secara efektif dan efisien dalam mencapai tujuan pembelajaran. Kegiatan pembelajaran secara efektif disini dimaksudkan agar pembelajaran tersebut dapat membawa hasil atau berhasil guna, dan kegiatan pembelajaran secara efisien dimaksudkan agar pembelajaran tersebut dapat berdaya guna atau tepat guna baik di lingkungan sekolah maupun dalam kehidupan bermasyarakat.

\section{Bentuk-Bentuk Muka Bumi}

Permukaan bumi yang kita tempati ini bentuknya bervariasi, ada yang datar, bergelombang, ada yang tinggi dan ada juga yang rendah.Bentuk permukaan bumi yang demikian disebut dengan relief permukaan bumi.Bentuk relief bumi tidak tetap, tetapi mengalami perubahan dari waktu ke waktu.

Perubahan relief permukaan bumi terjadi karena adanya tenaga geologi, yaitu tenaga pembentuk muka bumi dari dalam (endogen) dan tenaga pembentuk dari luar (eksogen).Relief permukaan bumi meliputi berbagai bentukan yang ada di daratan dan dasar laut. 


\section{Relief Daratan}

Daratan di permukaan bumi memiliki berbagai macam di antaranya berikut ini.

a. Dataranadalah suatu wilayah yang relatif landai mendekati rata. Wilayah dataran dapat dikelompokkan menjadi tiga kelompok, yaitu berikut ini.

$\checkmark$ Dataran pantai,yaitu dataran yang letaknya dekat pantai dengan ketinggian kurang dari 200 meter dari permukaan air laut, dan masih mengalami pengaruh laut secara langsung. Contoh Pantai Kuta Bali.

$\checkmark$ Dataran rendah, yaitu dataran yang tingginya sekitar $200-300$ meter di atas permukaan laut. Contoh daratan rendah Cianjur di Jawa Barat.

$\checkmark$ Dataran tinggi (plato),yaitu wilayah dataran yang terdapat di daerah dengan ketinggian lebih dari 1000 meter di atas permukaan laut. Contohnya dataran tinggi Dieng di Jawa Tengah dan dataran tinggi Bandung di Jawa Barat.

b. Bukit atau perbukitanadalah wilayah di permukaan bumi yang berketinggian antara 200 - 500 meter di atas permukaan laut dan disertai beberapa bagian yang merupakan lembah.

c. Gunungyaitu bentuk permukaan bumi yang menjulang tinggi dan memiliki puncak, lereng serta kaki gunung.

Pegununganadalah kumpulan atau gugusan beberapa gunung. Pegunungan dapat dikelompokkan menjadi dua jenis, yaitu: pertama, Pegunungan rendah, yaitu memiliki ketinggian antara 500 - 1.500 meter di atas permukaan laut; kedua, Pegunungan tinggi yaitu memiliki ketinggian lebih dari 1.500 meter di atas permukaan laut.

\section{Relief Dasar Laut}

Dasar laut memiliki berbagai macam bentukan, di antaranya berikut ini:

a. Landas/Paparan benua (continental shelf)yaitu dasar laut yang paling tepi dengan bentuk reliefnya menurun landai dari daratan benua menuju ke dalam laut, memiliki sudut kemiringan 10, dan kedalaman antara $0 \mathrm{~m}-$ 200 m. Contohnya Laut Jawa.

b. Lereng benua/Kaki benua/Tepi benua (continental slope)yaitu bagian relief dasar laut yang menurun tajam dan curam, kelanjutan dari landas benua atau sering disebut kaki benua, memiliki sudut kemiringan kurang 
dari 500 menuju ke dalam laut, dan kedalaman antara $200 \mathrm{~m}-1.500 \mathrm{~m}$. Contohnya Laut Cina Selatan.

c. Dataran laut dalam/Dataran abisal (deep sea plain/abbysal plain)merupakan wilayah relief dasar laut yang terletak pada kedalaman lebih dari $1.500 \mathrm{~m}$. Wilayah ini meliputi hampir dua pertiga relief dasar laut. Bentuk-bentuk relief dataran abisal bervariasi seperti punggung laut, dataran tinggi laut, gunung laut dengan puncak vulkaniknya menyembul ke atas permukaan laut sebagai pulau. Contohnya Punggung Atlantik Tengah.

Dasar laut sangat dalam (the deeps) yaitu bentuk relief dasar yang dicirikan dengan adanya palung laut dan lubuk laut. Palung laut merupakan dasar laut yang sangat dalam di atas $5.000 \mathrm{~m}$, curam, sempit, dan memanjang berbentuk huruf V. Contohnya Palung Banda $(7.440 \mathrm{~m})$. Sementara lubuk laut merupakan dasar laut yang sangat dalam, luas membentuk suatu cekungan seperti huruf U. Contohnya Cekungan Sulawesi.

\section{METODE}

Pada Penelitian ini digunakan jenispenelitian tindakan kelas, dengan pendekatan jenis penelitian kualitatif. Menurut Sapriyah (2009: 37) Penelitian tindakan kelas merupakan suatu pencermatan terhadap kegiatan belajar berupa sebuah tindakan yang sengaja dimunculkan dan terjadi dalam sebuah kelas secara bersamaan.Pendekatan kualitatif yang digunakan adalah prosedur penelitian yang menghasilkan data deskriptif berupa kata-kata tertulis atau lisan dari orang-orang dan perilaku dapat diamati.

\section{HASIL DAN PEMBAHASAN}

Hasil penilaian terhadap kemampuan siswa dalam memahami materi yang diajarkan pada siklus I ini dapat deskripsikan pada tabel berikut ini.

Tabel 1. Hasil Perolehan Nilai Siklus I

\begin{tabular}{|l|l|c|c|c|}
\hline NO & NAMA SISWA & SKOR & NILAI & KETERANGAN \\
\hline 1 & Aleksya P Mulo & 7 & 70 & Tuntas \\
2 & Adonia P Piga & 5 & 50 & Tidak Tuntas \\
3 & Anita Weubun & 6 & 60 & Tidak Tuntas \\
4 & Aleks Ice & 5 & 50 & Tidak Tuntas \\
5 & Arifin Amat & 6 & 60 & Tidak Tuntas \\
6 & Cindiawati Paulain & 5 & 50 & Tidak Tuntas \\
\hline
\end{tabular}




\begin{tabular}{|c|c|c|c|c|}
\hline 7 & Derik F Pareda & 6 & 60 & Tidak Tuntas \\
\hline 8 & Defi Lampa & 5 & 50 & Tidak Tuntas \\
\hline 9 & Derdi Valdo Tarinate & 9 & 90 & Tuntas \\
\hline 10 & Forbi Jekson & 5 & 50 & Tidak Tuntas \\
\hline 11 & Hendrika Maanana & 6 & 60 & Tidak Tuntas \\
\hline 12 & Hendrikel Abua & 9 & 90 & Tuntas \\
\hline 13 & Inggrit Jekni Bani & 6 & 60 & Tidak Tuntas \\
\hline 14 & Ismail Ajihar & 7 & 70 & Tuntas \\
\hline 15 & Jerfi Lodo & 5 & 50 & Tidak Tuntas \\
\hline 16 & Jerika Mulo & 5 & 50 & Tidak Tuntas \\
\hline 17 & Livia Datia Dorohubi & 5 & 50 & Tidak Tuntas \\
\hline 18 & Marsi Wane & 8 & 80 & Tuntas \\
\hline 19 & Marselina Lete & 7 & 70 & Tuntas \\
\hline 20 & Madolita Puasa & 8 & 80 & Tuntas \\
\hline 21 & Riski Nyari Gila & 6 & 60 & Tidak Tuntas \\
\hline 22 & Trifena Andriyani & 7 & 70 & Tuntas \\
\hline 23 & Makapilo & 6 & 60 & Tidak Tuntas \\
\hline 24 & $\begin{array}{l}\text { Yulius Gabiana } \\
\text { Yeheskel C Peleu }\end{array}$ & 5 & 50 & Tidak Tuntas \\
\hline & Jumlah & 149 & 1490 & \\
\hline & Rata-Rata & & 62.08 & \\
\hline \multicolumn{3}{|c|}{ Siswa yang tuntas 8 orang } & $16.66 \%$ & \\
\hline \multicolumn{3}{|c|}{ Siswa yang tidak tuntas 15 orang } & 83.34 & \\
\hline
\end{tabular}

Tabel 2. Distribusi Frekuensi Hasil Belajar Siswa Pada Siklus I

\begin{tabular}{|c|c|c|c|}
\hline No & Nilai(x) & Frekuensi & F.x \\
\hline 1 & 90 & 2 & 180 \\
\hline 2 & 80 & 2 & 160 \\
\hline 3 & 70 & 4 & 280 \\
\hline 4 & 60 & 7 & 420 \\
\hline 5 & 50 & 9 & 450 \\
\hline \multicolumn{2}{|r|}{ Jumlah } & N $=\mathbf{2 4}$ & $\Sigma \mathbf{f . x}=\mathbf{1 . 4 9 0}$ \\
\hline
\end{tabular}

Sumber Olahan Data primer 2016

$$
\overline{\mathrm{X}}=\frac{\sum F \cdot X}{N}
$$

Keterangan

$\overline{\mathrm{X}}=$ Rata-rata hasil belajar Siswa

$\Sigma F x=$ Jumlah skor yang di peroleh Siswa

$\mathrm{N}$ = Jumlah Siswa

$\bar{X}=\frac{1.490}{z 4}=62.08$

$\bar{X}=62,08$ 


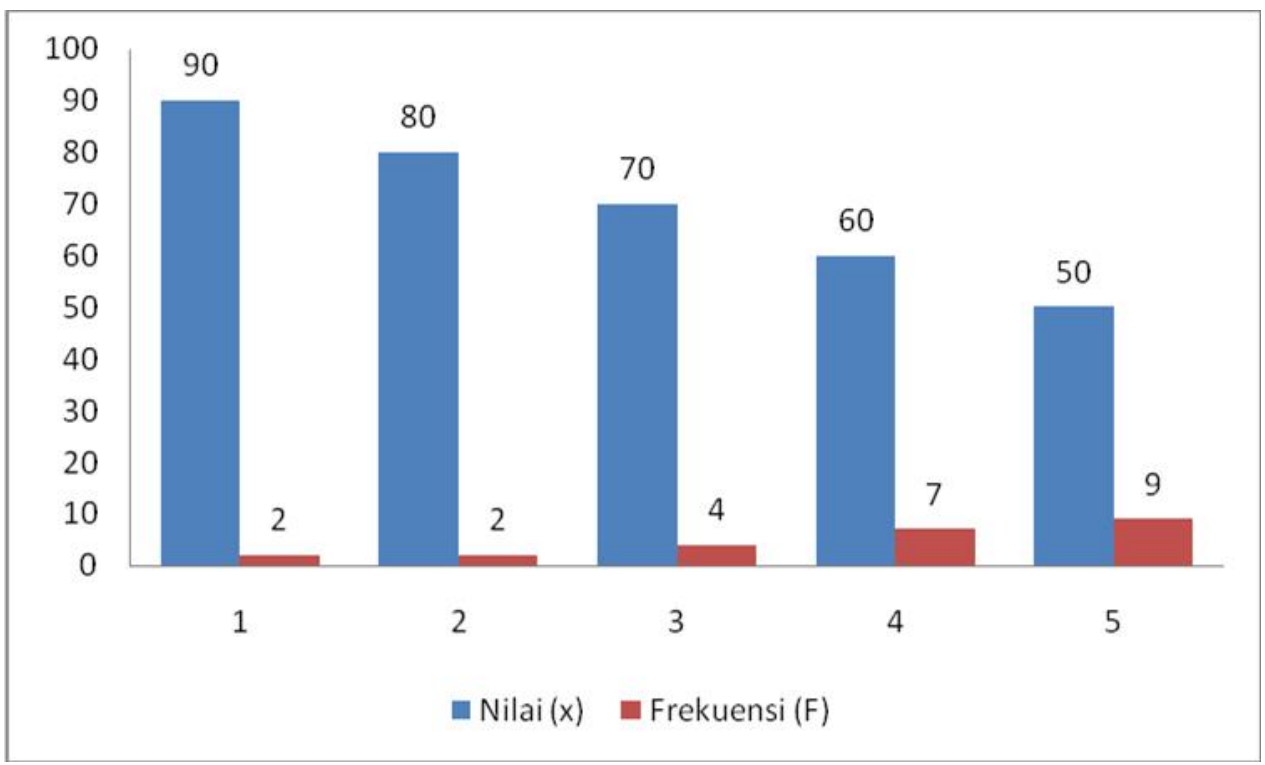

Diagram 1. Distribusi frekuensi Hasil Belajar Siswa Pada Siklus I

Berdasarkan hasil belajar siswa yang ditunjukkan dengan kemampuan menjawab pertanyaan yang berhubungan dengan materi yang telah diinformasikan seperti pada tabel di atas, tampak bahwa secara umum hasil belajar siswa dalam penguasaan materi baru berada pada kondisi yang cukup baik dengan pencapaian rata-rata 62,08. Hal ini di karenakan dalam penerapan metode pembelajaran Konstruktivisme belum sepenuhnya di mengerti oleh siswa, sehingga pencapaian hasil belajar pada siklus I belum berhasil.

Sementara hasil tes siklus II untuk mengukur tingkat kemampuan siswa dalam memahami materi bentuk-bentuk muka bumi yang diberikan dengan menggunakan metode pembelajaran konstruktivisme.

Tabel 3.Hasil Perolehan Nilai Siklus II

\begin{tabular}{|c|l|c|c|c|}
\hline NO & \multicolumn{1}{|c|}{ NAMA SISWA } & SKOR & NILAI & KETERANGAN \\
\hline 1 & Aleksya P Mulo & 8 & 80 & Tuntas \\
2 & Adonia P Piga & 7 & 70 & Tidak Tuntas \\
3 & Anita Weubun & 7 & 70 & Tuntas \\
4 & Aleks Ice & 6 & 60 & Tidak Tuntas \\
5 & Arifin Amat & 8 & 80 & Tuntas \\
6 & Cindiawati Paulain & 6 & 60 & Tidak Tuntas \\
7 & Derik F Pareda & 7 & 70 & Tuntas \\
8 & Defi Lampa & 9 & 60 & Tidak Tuntas \\
9 & Derdi Valdo Tarinate & 5 & 90 & Tuntas \\
10 & Forbi Jekson & 8 & 50 & Tidak Tuntas \\
11 & Hendrika Maanana & 80 & Tuntas \\
\hline
\end{tabular}




\begin{tabular}{|c|c|c|c|c|}
\hline 12 & Hendrikel Abua & 9 & 90 & Tuntas \\
\hline 13 & Inggrit Jekni Bani & 6 & 60 & Tidak Tuntas \\
\hline 14 & Ismail Ajihar & 7 & 70 & Tuntas \\
\hline 15 & Jerfi Lodo & 6 & 60 & Tidak Tuntas \\
\hline 16 & Jerika Mulo & 7 & 70 & Tuntas \\
\hline 17 & Livia Datia Dorohubi & 5 & 50 & Tidak Tuntas \\
\hline 18 & Marsi Wane & 9 & 90 & Tuntas \\
\hline 19 & Marselina Lete & 8 & 80 & Tidak Tuntas \\
\hline 20 & Madolita Puasa & 8 & 80 & Tuntas \\
\hline 21 & Riski Nyari Gila & 8 & 80 & Tuntas \\
\hline 22 & Trifena Andriyani Makapilo & 9 & 90 & Tuntas \\
\hline 23 & Yulius Gabiana & 7 & 70 & Tuntas \\
\hline 24 & Yeheskel C Peleu & 5 & 50 & Tidak Tuntas \\
\hline & Jumlah & 171 & 1710 & \\
\hline & Rata-Rata & & 71.25 & \\
\hline \multicolumn{3}{|c|}{ Siswa yang tuntas 16 orang } & $66.67 \%$ & \\
\hline \multicolumn{3}{|c|}{ Siswa yang tidak tuntas 8 orang } & $33.33 \%$ & \\
\hline
\end{tabular}

Tabel 4. Distribusi Frekuensi Hasil Belajar Siswa Pada Siklus II

\begin{tabular}{|c|c|c|c|}
\hline No & Nilai $(\mathbf{X})$ & Frekuensi(F) & F.x \\
\hline 1 & 90 & 4 & 360 \\
\hline 2 & 80 & 6 & 480 \\
\hline 3 & 70 & 6 & 420 \\
\hline 4 & 60 & 5 & 300 \\
\hline 5 & 50 & 3 & 150 \\
\hline & Jumlah & $\mathbf{N = 2 4}$ & $\Sigma \mathbf{f . x}=\mathbf{1 . 7 1 0}$ \\
\hline
\end{tabular}

Sumber Olahan Data primer 2016

$$
\overline{\mathrm{X}}=\frac{\Sigma F, X}{N}
$$

Keterangan

$$
\begin{aligned}
& \bar{X}=\text { Rata-rata hasil belajar Siswa } \\
& \Sigma F x=\text { Jumlah skor yang di peroleh Siswa } \\
& N=\text { Jumlah Siswa } \\
& \bar{X}=\frac{1.710}{24}=71.25 \\
& \bar{X}=71.25
\end{aligned}
$$




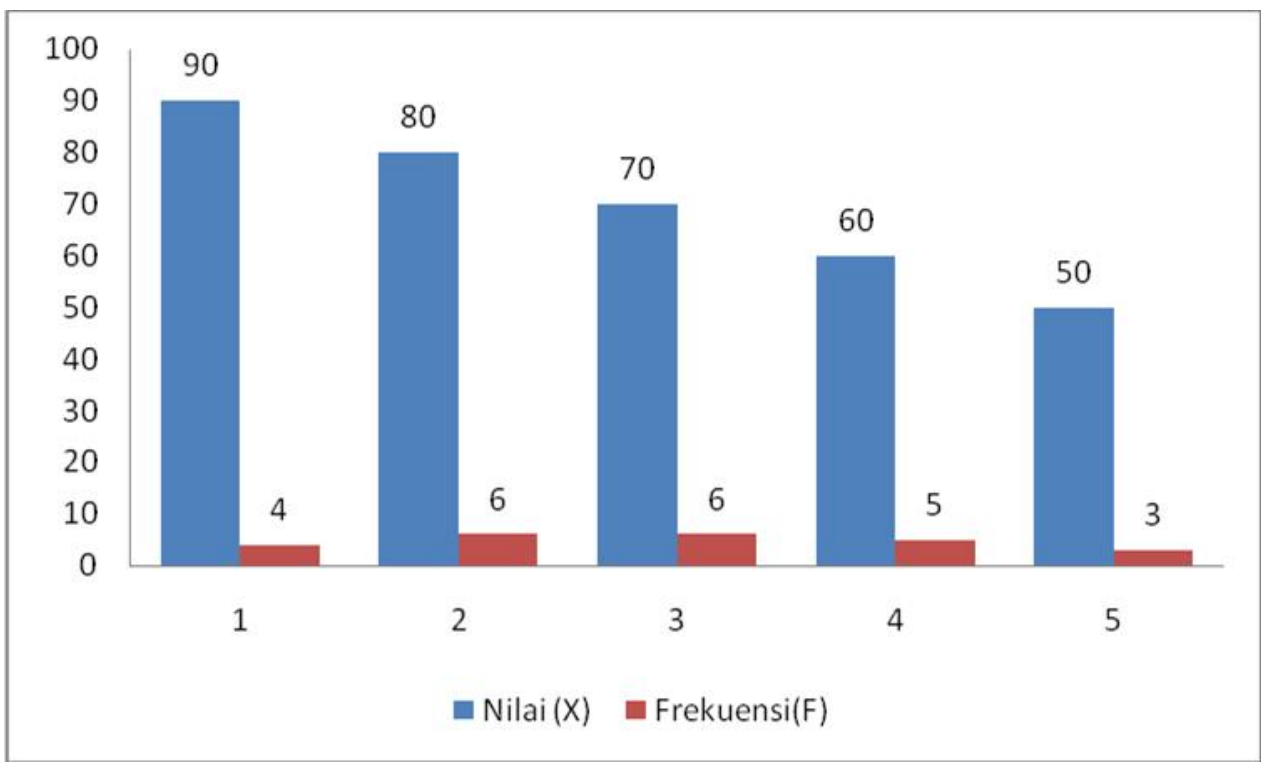

Diagram 2. Distribusi frekuensi Hasil Belajar Siswa Pada Siklus II

Berdasrkan hasil tes siklus II yang dilakukan dapat di ketahui bahwa skor dan nilai rata-rata siswa pada pembelajaran siklus II sebesar 71,25. Hal ini menandakan bahwa adanya peningkatan hasil belajar dari siklus I ke siklus II. Dimana siklus I nilai rata-rata yang di peroleh oleh siswa sebesar 63,33. Dari tes siklus II dapat di nyatakan bahwa kemampuan siswa mengalami peningkatan dalam memahami materi yang diajarkan

Tabel 5. Perbandingan Hasil Belajar Siswa Pada Siklus I Dan II

\begin{tabular}{|c|c|c|}
\hline No & Siklus I & Siklus II \\
\hline 1 & 62,08 & 71,25 \\
\hline
\end{tabular}




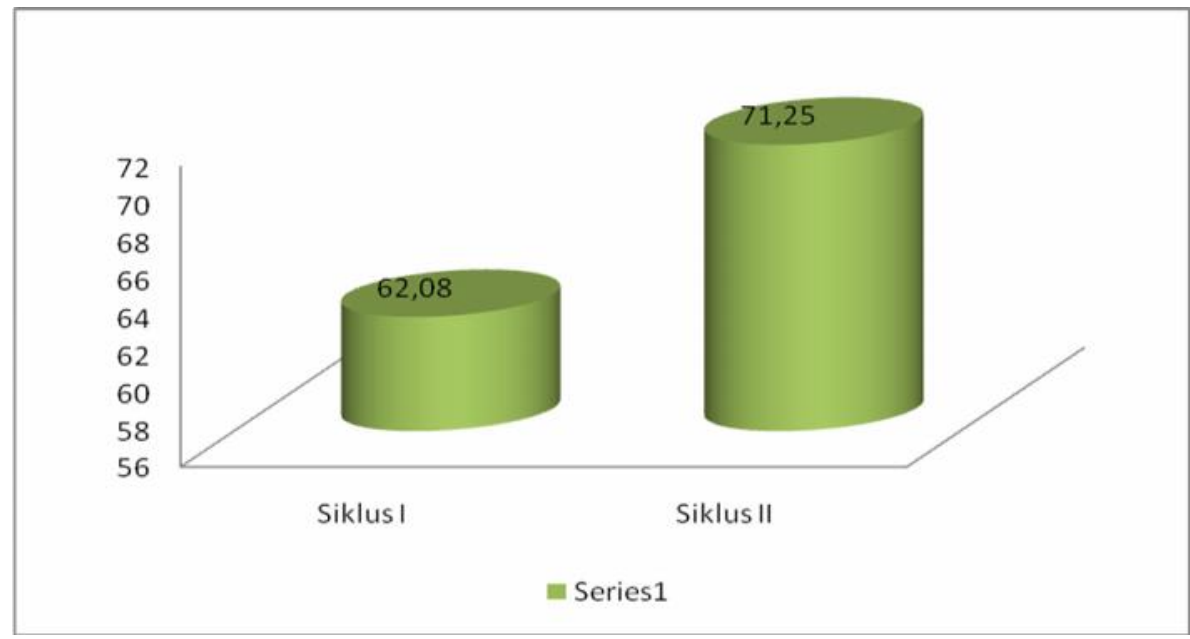

Diagram 3. Perbandingan Hasil Belajar Siswa pada Siklus I dan II

Berdasarkan hasil analisis pada siklus I di atas , perolehan nilai rata-rata siswa masi belum memenuhi standar KKM, yaitu hanya 62,08. Sementara standar KKM yang digunakan di SMP Gotong Royong sebesar 65. Maka siswa yang semula memiliki skor hasil belajar geografi yang rendah dapat di tingkatkan melalui tindakan pada siklus II skor rata-rata yang di peroleh siswa mengalami peningkatan sebesar 71,25 pada siklus II. Berdasarkan data-data tersebut diperoleh bahwa pembelajaran melalui metode pembelajaran kontruktivisme pada siklus II meningkat.

\section{SIMPULAN}

Berdasarkan hasil penelitian tindakan kelas yang berlangsung selama dua siklus ini, maka dapat disimpulkan bahwa pelaksanaan pembelajaran dengan menggunakan metode kontruktivisme untuk meningkatkan hasil belajar siswa pada mata pelajaran geografi Kelas VII SMP Gotong Royong Tobelo. Hasil pada siklus I adalah 63,33 nilai tersebut belum mencapai kriteria ketuntasan minimun. Hasil pada siklus II mengalami peningkatan yaitu dengan nilai 71,25, maka siswa telah mencapai kriteria ketuntasan minimum sebanyak $66,67 \%$ dari semua siswa yang berada di kelas tersebut. 


\section{DAFTAR PUSTAKA}

Arikunto, Suharsimi. 2005. Dasar-dasar Evaluasi Pendidikan. Bumi Aksara: Jakarta.

Arikunto, Suharsimi. 2010. Penelitian Tindakan Kelas. PT Bumi Aksara: Jakarta.

Baharudin, Esa Nur Wahyuni, 2007. Teori Belajar dan Pembelajaran, Ar-Ruz Media: Yogyakarta.

Dahar, Ratna Wilis. 2002. Teori-teori Belajar. Erlangga: Jakarta.

Dahlan. 1990. Model-ModelMengajar. Cv. Diponogoro: Bandung.

Dimyati., Mudjiono. 2002. Belajar Dan Pembelajaran. Rineka Cipta: Jakarta.

Fakih. 1998. Pengantar Ilmu Pendidikan. UPT MKK UNNES: Semarang.

Muliawan J. Ungguh. 2014. Metodelogi Penelitian Pendidikan. Gava Media: Yogyakarta.

Muslich, Mansur. 2009. KTSP Pembelajaran Berbasis Kompetensi dan Konseptual. Bumi Aksara: Jakarta.

Nasution. 1997. Metode Penelitian Naturalistik Kualitatif. Tarsito: Bandung.

Sapriyah. 2009. Penelitian Tindakan Kelas. Widya Karya: Semarang.

Sudjana, Nana. 2009. Dasar-dasar Proses Belajar Mengajar, Sinar Baru Algensindo: Bandung.

Sumiati dan Asra. 2009. Metode Pembelajaran. Cv. Wacana Prima: Bandung.

Slameto. 2003. Belajar dan Faktor-faktor yang Mempengaruhinya, Rineka Cipta: jakarta.

Sudjana, Nana. 2004. Penilaian Hasil Proses Belajar Mengajar, Remaja Rosda Karya: Bandung. 